\title{
Experimental study of pressure flushing of non-cohesive sediment through slotted pipe bottom outlet
}

\section{Estudo experimental de descarga de sedimentos não-coesivos através de descarregador de fundo tipo tubo ranhurado}

Felipe Azevedo Paulo ${ }^{1}$ (D), Aline Saupe Abreu${ }^{1}$ (D), Maurício Dai Prá ${ }^{1}$ (D), Luiz Augusto Magalhães Endres ${ }^{1}$ (D), Rute Ferla ${ }^{1}$ (D) \& Eder Daniel Teixeira ${ }^{1}$ (D)

${ }^{1}$ Instituto de Pesquisas Hidráulicas, Universidade Federal do Rio Grande do Sul, Porto Alegre, RS, Brasil

E-mails: felipe.azevedo.paulo@gmail.com (FAP), alsaupe@gmail.com (ASA),mauricio.daipra@ufrgs.br (MDP), endres@ufrgs.br (LAME), ruteferla@hotmail.com (RF), eder.teixeira@ufrgs.br(EDT)

Received: April 25, 2020 - Revised: October 25, 2020 - Accepted: October 26, 2020

\begin{abstract}
Among several techniques for prevention and mitigation of reservoir sedimentation, bottom outlets arise as a means of removing sediment deposited close to the dam. Given the reduced sediment removal provided by traditional bottom outlets under pressure flushing conditions, this article proposes a new type of structure that aims to increase sediment removal in the direction parallel to the dam axis. An experimental installation was employed to evaluate its operation as a function of the variation of its diameter and flow and sediment characteristics. Through analysis of the bathymetry generated by the structure, a dimensionless relation for predicting the scour pit length was obtained, presenting good fitness to the experimental data.
\end{abstract}

Keywords: Reservoir sedimentation; Bottom outlet; Pressure flushing; Sediment; Water intake.

\section{RESUMO}

Entre as medidas de prevenção e mitigação da sedimentação em reservatórios, descarregadores de fundo se apresentam como uma forma de remover sedimentos que se depositam junto ao barramento. Dada a restrita remoção de sedimento gerada pelos descarregadores tradicionais em condições de pressure flushing, este artigo propõe uma nova configuração de descarregador de fundo que visa aumentar o alcance de remoção de sedimentos no sentido paralelo ao eixo da barragem. Foi empregada uma instalação experimental para avaliar seu funcionamento em função da variação de seu diâmetro e de características do escoamento e do sedimento. Através da análise da batimetria gerada pela estrutura, desenvolveu-se uma relação adimensional que estima o alcance de remoção de sedimento, apresentando bom ajuste aos dados experimentais.

Palavras-chave: Assoreamento de reservatórios; Descarregador de fundo; Pressure flushing; Sedimento; Tomada de água. 


\section{INTRODUCTION}

Reservoir sedimentation is a major problem in dam operation. Sediment accumulation inside the reservoir reduces water storage capacity besides hampering the operation of water intakes, clogging them, and turbines, causing abrasion of their components (Schleiss et al., 2016). Globally, sedimentation causes loss of $1 \%$ of total storage volume every year (George et al., 2017; Mahmood, 1987; World Commission on Dams, 2000) with greater values observed in Asia, where it can be 1.7\% (Wen Shen, 1999). In countries like Brazil, where $66 \%$ of electric energy comes from hydropower dams (Empresa de Pesquisa Energética, 2019), reservoir sedimentation is an issue with growing importance. Besides the loss of storage capacity, sedimentation modifies river morphology and nutrient transport related to sediment due to the interruption of sediment flow downstream (Juracek, 2015; Mahmood, 1987).

There is a global trend for a growing demand for water and energy (United Nations Educational, Scientific and Cultural Organization, 2019). Therefore, the life expectancy of reservoirs must be maximized, because the construction of new dams is onerous, bound to extensive processes of environmental licensing and depends on the existence of suitable places for its installation - which are increasingly scarce (Wen Shen, 1999). Mitigation and prevention of sedimentation constitute essential tasks in achieving that objective.

Bottom outlets are useful tools for sediment removal close to the dam since other sediment management techniques hold considerable disadvantages: mechanical dredging is expensive; plans for adopting soil control measures to reduce erosion in the watershed depend on the coordination of several parts of society; by-pass structures are unusual in Brazilian and other countries realities (Wen Shen, 1999).

Bottom outlets usage as a sedimentation mitigation measure in dams is achieved under two possible conditions: drawdown flushing and pressure flushing (Lai \& Shen, 1996). Drawdown flushing consists of eroding sediment deposits and routing them downstream through a complete drawdown of water level and consequent emptying of the reservoir (what restrains its operation), resulting in free surface flow along all bottom outlet length (Kondolf et al., 2014). In this way, storage capacity is recovered from sediment deposits by eroding them like a river. This technique has been investigated by several authors through physical and mathematical modelling (Atkinson, 1996; Chaudhary et al., 2019; Lai \& Shen, 1996; Taleb Bidokhti \& Naghshineh, 2004; Wen Shen, 1999) and has been successfully applied worldwide (Chaudhry \& Rehman, 2012; Kondolf et al., 2014). On the other hand, operation under pressure flushing conditions only serves for scouring sediments deposited in the vicinity of water intakes (Kondolf et al., 2014; Wen Shen, 1999). Activating the bottom outlet makes the flow concentrate around the structure, generating high velocities and, therefore, high shear stresses that destabilize the sediment deposit and trigger, locally, the erosive process. However, flow velocity decreases in the upstream direction faster than the square of the distance (Mahmood, 1987). This is why the erosion due to this technique only affects a region restricted to the vicinity of the bottom outlet, forming a scour cone upstream (Meshkati et al., 2010). This forces water intakes to generally be placed near bottom outlets to make its desilting possible (Kamble et al., 2018).
Several authors have proposed equations for predicting the dimensions of the scour cone and the efficiency of bottom outlets as a function of parameters of sediment, flow, and geometry of the bottom outlet (Abreu, 2019; Emamgholizadeh, 2012; Emamgholizadeh et al., 2006; Emamgholizadeh \& FathiMoghdam, 2014; Fathi-Moghadam et al., 2010; Kamble et al., 2018; Meshkati et al., 2009, 2010; White \& Bettess, 1984). The majority of the studies hitherto aimed to describe the functioning of bottom outlets of circular cross section installed in the face of the dam, being scarce investigations of new configurations. Madadi et al. (2017) propose an interesting new geometry (different from this article's proposal) consisting of a pipe with semicircular cross section that projects itself towards the reservoir orthogonally to the dam. The authors state that it increases the efficiency of pressure flushing and the dimensions of the flushing cone in relation to those obtained with traditional bottom outlets.

Since increasing the removal of deposited sediment through bottom outlets may contribute to maximizing the lifespan of reservoirs, this article presents a new configuration of bottom outlet that aims to promote more sediment removal in the direction parallel to the dam's axis, allowing more freedom in placing water intakes. The proposed bottom outlet structure, called slotted pipe bottom outlet, is composed of a pipe with an orifice at its end and slots parallel to its cross section that is placed parallel to the dam's axis. Experimental studies were conducted in order to verify the influence of the variation of pipe diameter, the density of sediments and discharge in the functioning of the structure under pressure flushing conditions. This article presents an analysis of the effect of the bottom outlet regarding the shape of the erosion generated and a dimensionless relation for predicting the length of the scour pit as a function of flow, sediment, and bottom outlet geometric characteristics.

\section{EXPERIMENTAL SET-UP}

Experiments were conducted at the Hydraulic Works Laboratory (LOH, acronym in Portuguese) of Rio Grande do Sul Federal University (UFRGS, acronym in Portuguese). The experimental installation, as shown in Figure 1, represents a hypothetic dam equipped with a bottom outlet and a sediment deposit upstream. The discharge was measured by two Krohne Conaut Optiflux 2000F flow meters, one measures discharge values up to $15 \mathrm{~m}^{3} / \mathrm{h}$ and the other up to $500 \mathrm{~m}^{3} / \mathrm{h}$ with a precision of $\pm 0.1 \%$. In the center of the wall that represents the dam, there was a $100 \mathrm{~mm}$ diameter circular orifice, which received the flow from the slotted pipe bottom outlet. The invert of the bottom outlet was $17 \mathrm{~cm}$ above the metallic channel floor. The channel had an on-rail movable mechanism used to perform the bathymetric surveys of the sediment deposit. Parallel to the dam wall was placed the slotted pipe bottom outlet as can be seen in Figure 2.

Pipe lengths were defined through previous experiments carried out to avoid the scour pit from reaching the sidewalls of the channel. Slot shape (vertical, extending from the obvert to half the circumference) was defined through previous experiments realized to avoid its obstruction by sediment particles. Four nominal PVC diameters (DN) were used: 32, 50, 75 and $100 \mathrm{~mm}$. Bottom outlet length (L) for each $\mathrm{DN}$ is; respectively; $45.4 \mathrm{~cm}$; 


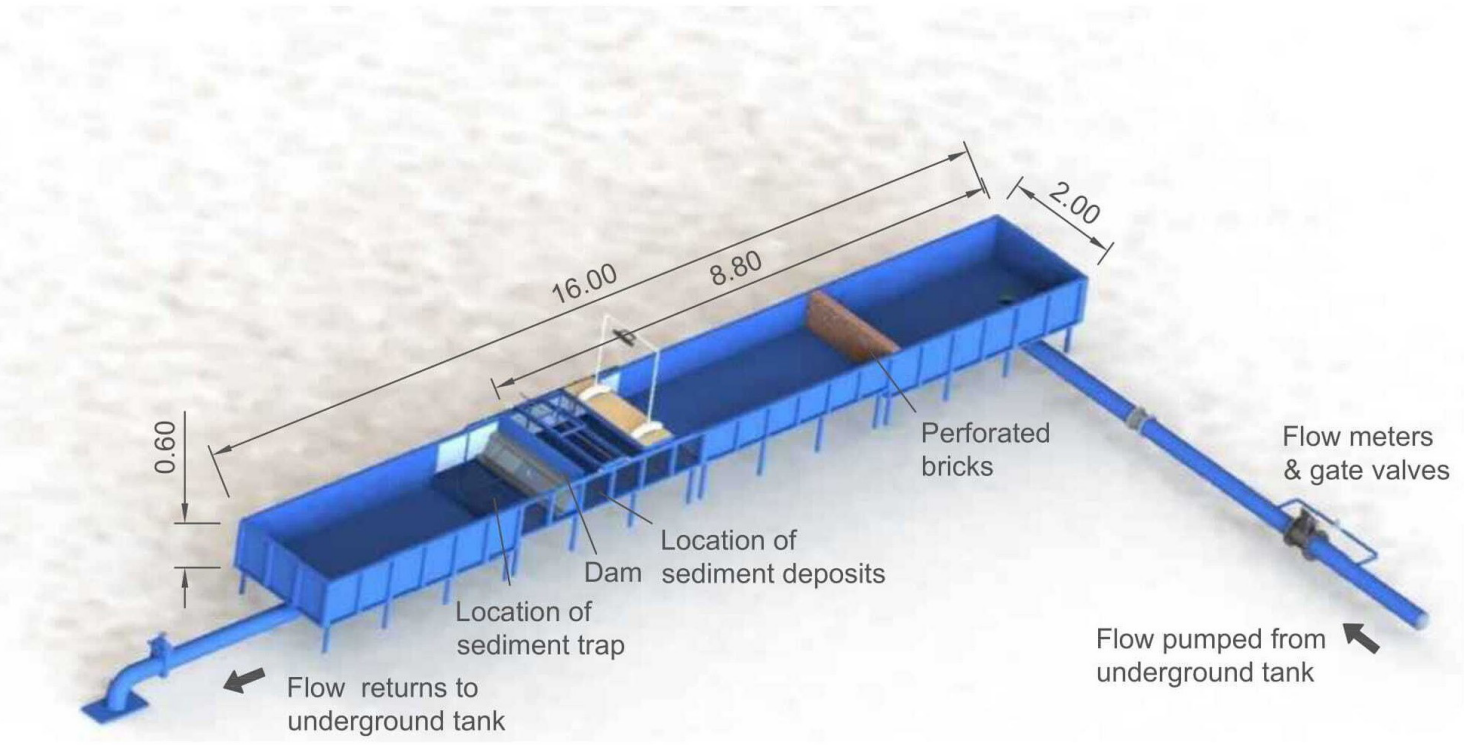

Figure 1. Experimental installation, dimensions in meters (modified after Abreu et al., 2018).

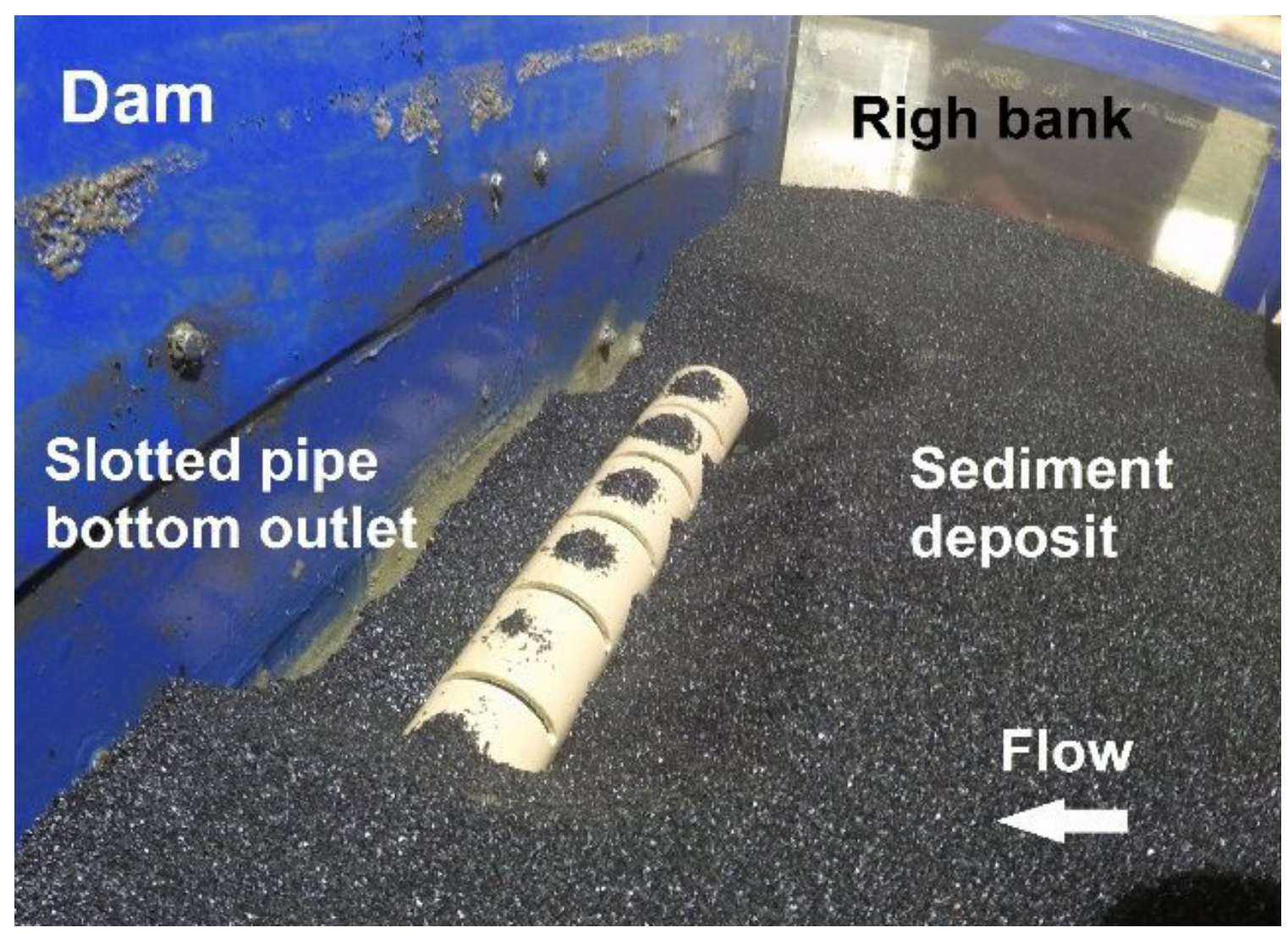

Figure 2. Slotted pipe bottom outlet.

$75.0 \mathrm{~cm} ; 49.4 \mathrm{~cm}$ and $53.2 \mathrm{~cm}$. The distance between slots is of one nominal diameter and its width is $10 \%$ one nominal diameter (see Figure 3). This configuration was chosen as the most adequate after previous experiments that aimed to maximize the dimension of the erosion pit and minimize slot obstruction.

Sediments were selected to cover a wide range of densities and, thus, verify its influence in the process of sediment removal through the bottom outlet. Tyre rubber granules (mean density of $1080 \mathrm{~kg} / \mathrm{m}^{3}$; median diameter $\left(\mathrm{d}_{50}\right)$ of $1.18 \mathrm{~mm}$, standard deviation $\left(\mathrm{d}_{84} / \mathrm{d}_{16}\right)^{0.5}$ of 0.71 , shape factor of 0.63 and repose angle of $46^{\circ}$ (Campello, 2017)) and sand (density of $2610 \mathrm{~kg} / \mathrm{m}^{3}$, median diameter $\left(\mathrm{d}_{50}\right)$ of $0.35 \mathrm{~mm}$, standard deviation $\left(\mathrm{d}_{84} / \mathrm{d}_{10}\right)^{0,5}$ of 0.61 and repose angle of $29.5^{\circ}$ (Abreu, 2019)) were employed as non-cohesive sediments. The sediment deposit had a constant thickness of $13 \mathrm{~cm}$ over the invert of the bottom outlets in all experiments. The topography of the scoured sediment deposit 


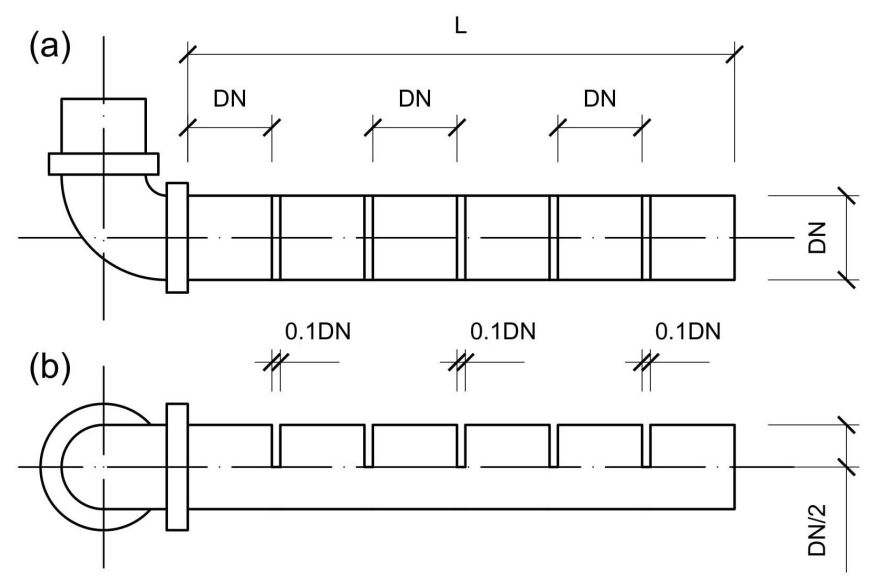

Figure 3. Plan (a) and front (b) views of the slotted pipe bottom outlet and its dimensions.

was surveyed with a laser distance measurer of $\pm 1 \mathrm{~mm}$ accuracy and the water level was assessed with a point gauge of $\pm 0.1 \mathrm{~mm}$ accuracy.

\section{EXPERIMENTAL PROCEDURE}

With the bottom outlet closed by downstream, the water was pumped to the channel until it reached a level close to the water level required for the beginning of the experiment. Then, the inflow was stopped and the sediment deposit was leveled. After that, inflow started again, but this time with the discharge value intended for the experiment. The bottom outlet was opened when the water level reached the intended value. From this moment, measures of discharge and water level were taken every 20 min until its stabilization. The experiment starts in unsteady state because it was not known beforehand which water level corresponded to the desired discharge through the bottom outlet. Therefore, as the discharge was kept constant, the water level rose until the pumped inflow matched the discharged outflow. The water level was deemed stable when two successive measures matched with a tolerance of $0.1 \mathrm{~mm}$. At this moment, if the sediment removal had already stopped (visual verification), the steady state was reached and the final measures of water level and discharge were taken as the boundary conditions that generated the scour pit observed and the experiment was ended. If the sediment removal had not stopped when the water level stabilized, the experiment continued until there was no more sediment movement. In general, sediment removal stopped much earlier than the stabilization time for water level. Stabilization time ranged from $40 \mathrm{~min}$ to $4 \mathrm{~h}$. Afterwards, the pump was turned off and the channel was drained by the same inflow pipe with a low discharge (about $1.5 \mathrm{l} / \mathrm{s}$ ) to avoid destabilization of the scour pit. With the channel empty, the $\mathrm{x}, \mathrm{y}$ and $\mathrm{z}$ coordinates of the bathymetry generated in the sediment deposit were measured moving the laser distance measurer with the on-rail movable mechanism. The resolution of the measurements was $4 \mathrm{~cm}$ in the horizontal plane and $1 \mathrm{~mm}$ in the vertical plane. The combinations of discharge and water level over the slot base $\left(\mathrm{H}_{\mathrm{w}}\right)$ for each material and diameter can be seen in Table 1. In
Table 1. Range of boundary conditions in the experiments.

\begin{tabular}{|c|c|c|c|c|}
\hline \multirow{2}{*}{$\begin{array}{c}\mathrm{DN} \\
(\mathrm{mm})\end{array}$} & \multicolumn{2}{|c|}{ Rubber } & \multicolumn{2}{|c|}{ Sand } \\
\hline & $\begin{array}{c}\text { Discharge } \\
(1 / \mathrm{s})\end{array}$ & $\mathrm{H}_{\mathrm{w}}(\mathrm{m})$ & $\begin{array}{c}\text { Discharge } \\
(1 / \mathrm{s})\end{array}$ & $\mathrm{H}_{\mathrm{w}}(\mathrm{m})$ \\
\hline \multirow[t]{4}{*}{32} & - & - & 0.77 & 0.347 \\
\hline & - & - & 0.82 & 0.358 \\
\hline & - & - & 0.87 & 0.399 \\
\hline & - & - & 0.88 & 0.399 \\
\hline \multirow[t]{9}{*}{50} & 1.23 & 0.182 & 1.26 & 0.162 \\
\hline & 1.70 & 0.245 & 1.30 & 0.180 \\
\hline & 1.70 & 0.247 & 1.70 & 0.251 \\
\hline & 2.15 & 0.395 & 1.72 & 0.249 \\
\hline & 2.40 & 0.382 & 2.14 & 0.370 \\
\hline & - & - & 2.15 & 0.368 \\
\hline & - & - & 2.19 & 0.379 \\
\hline & - & - & 2.19 & 0.380 \\
\hline & - & - & 2.27 & 0.394 \\
\hline \multirow[t]{11}{*}{75} & 4.39 & 0.333 & 4.00 & 0.263 \\
\hline & 4.50 & 0.305 & 4.01 & 0.247 \\
\hline & 4.97 & 0.356 & 4.50 & 0.270 \\
\hline & 4.99 & 0.356 & 4.50 & 0.273 \\
\hline & 5.00 & 0.363 & 5.00 & 0.313 \\
\hline & 5.00 & 0.373 & 5.00 & 0.315 \\
\hline & 5.19 & 0.379 & 5.16 & 0.334 \\
\hline & 5.20 & 0.380 & 5.20 & 0.328 \\
\hline & - & - & 5.20 & 0.342 \\
\hline & - & - & 5.70 & 0.395 \\
\hline & - & - & 5.70 & 0.397 \\
\hline \multirow[t]{7}{*}{100} & 8.60 & 0.207 & 8.40 & 0.276 \\
\hline & 8.60 & 0.248 & 8.45 & 0.276 \\
\hline & 8.60 & 0.273 & 8.80 & 0.284 \\
\hline & 9.00 & 0.279 & 8.80 & 0.303 \\
\hline & 9.00 & 0.294 & 9.50 & 0.303 \\
\hline & 9.50 & 0.332 & 9.50 & 0.336 \\
\hline & 9.50 & 0.378 & - & - \\
\hline
\end{tabular}

total, 50 experiments were conducted with at least one repeat for each combination of material, diameter, and discharge.

\section{DIMENSIONAL ANALYSIS}

The hydraulic and geometric parameters considered in the analysis of the results were the mean inflow velocity at the slots $\left(\mathrm{u}_{\mathrm{r}}\right)$, water column over the slot base $\left(\mathrm{H}_{\mathrm{w}}\right)$, sediment density $\left(\varrho_{\mathrm{s}}\right)$, fluid density $(\varrho)$, internal diameter of the structure $\left(\mathrm{D}_{\text {int }}\right)$, median diameter of sediment or $\mathrm{d}_{50}(\mathrm{~d})$, sediment column above the slot base at a certain point in the scour profile $\left(\mathrm{H}_{\mathrm{s}}\right)$, gravitational acceleration (g) and length of scour pit in the upstream direction at a certain point in the scour profile or flushing range $\left(\mathrm{L}_{\mathrm{s}}\right)$. The coordinate system adopted does not match with $\mathrm{x}, \mathrm{y}$ and $\mathrm{z}$ coordinates from the bathymetry (situation in which all bottom outlets had their inverts at the same $z$ value). A translation of the coordinates was made in order to match the origin of $\mathrm{L}_{\mathrm{s}}, \mathrm{H}_{\mathrm{s}}$ and $\mathrm{H}_{\mathrm{w}}$ values with the slot base and the external diameter of the slotted pipe bottom outlet as schematized in Figure 4.

From Vaschy-Buckingham $\pi$ theorem and the evaluation of dimensionless groups used by other authors (Abreu, 2019; 


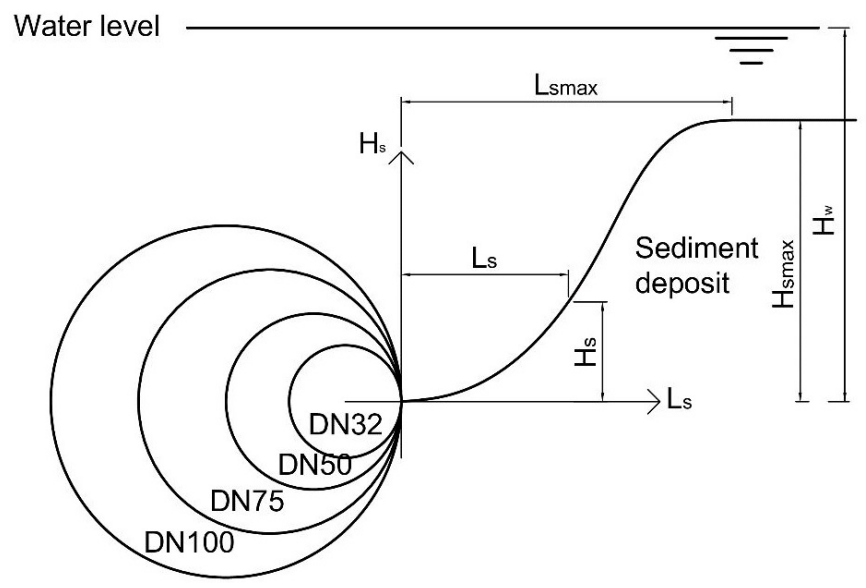

Figure 4. Coordinate system employed in the analysis.

Emamgholizadeh et al., 2006; Fathi-Moghadam et al., 2010; Meshkati et al., 2010), the following dimensionless parameters turned up relevant in the representation of the scour pit geometry:

$$
f\left(\frac{H_{w}}{H_{s}}, \frac{u_{r}}{\sqrt{g d}}, \frac{L_{s}}{D_{i n t}}, \frac{\rho_{s}-\rho}{\rho}\right)=0
$$

The aim is to obtain a relationship among dimensionless groups that allow estimation of the length of the sediment removal caused by the slots of the slotted pipe bottom outlet.

\section{RESULTS AND DISCUSSION}

\section{Form of scour pit}

Two situations were observed in the experiments (see Figure 5): in the called Case A, the sediments were not removed along all the bottom outlet extension and, in the called Case B, sediment removal occurred in all the extension of the structure. Case A was observed with diameters DN32 and DN50 and Case B was observed with DN75 and DN100 regardless of sediment type and discharge value.

Flow in Case A was not able to clear all pipe extension, in a way that sediment removal occurred only through slots. The pit generated possesses an approximately constant cross section since all slots have the same geometry and are equally spaced. In Case B, the flow removed sediment along the entire structure, exposing the circular orifice at its end. Consequently, sediment removal took place through slots and orifice. It was observed that the maximum flushing range $\left(\mathrm{L}_{\text {smax }}\right)$ through the pipe end is, on average, $40 \%$ greater than $\mathrm{L}_{\text {smax }}$ due to slots.

\section{Sediment removal process}

The driving force for the flow through the bottom outlet is the pressure gradient between upstream and downstream. If the water column is too low (little relation $\mathrm{H}_{\mathrm{w}} / \mathrm{H}_{\mathrm{s}}$ ), pressure may not be sufficient to overcome the initial resistance represented by

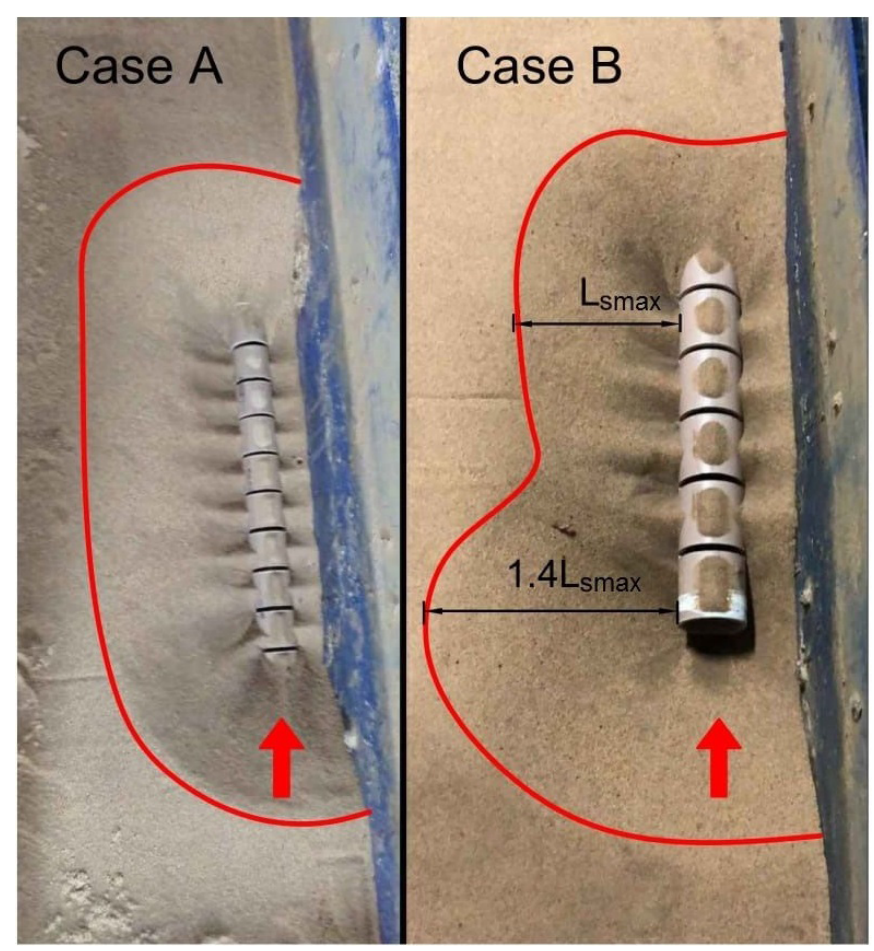

Figure 5. Types of scour pit: sediment removal only through slots (Case A; DN50; 2.15 l/s) and removal through slots and circular orifice (Case B; DN75; 5.70 l/s).

sediment despite the activation of the structure. In the majority of experiments, sediment motion started immediately after the opening of the bottom outlet. Only in DN50 experiments with discharges $1.23 \mathrm{l} / \mathrm{s}$ and $1.30 \mathrm{l} / \mathrm{s}$ and two DN75 experiments with $4.00 \mathrm{l} / \mathrm{s}$ the initial water level was not enough to promote sediment removal. In those cases, the water level upstream of the dam rose until the pressure gradient was sufficient for transporting sediment inside the pipe and generating velocities that prevented it from depositing. Relation $\mathrm{H}_{\mathrm{w}} / \mathrm{H}_{\mathrm{s}}$ when movement began in those experiments were $1.21 ; 1.11 ; 1.38$ and 1.31 respectively. These observations agree with the statement of Fathi-Moghadam et al. (2010) that pressure is the most relevant variable for the initiation of particle movement through bottom outlets under pressure flushing conditions.

Scour pit development occurred rapidly in all experiments. Soon after the initiation of movement, a great amount of sediment was routed through the bottom outlet, generating a heavily sediment-laden flow downstream of the dam. However, the sediment load gradually decreased and by the end of the first three minutes, approximately, the flow did not present turbidity anymore. Stabilization of the scour pit happened when the increase of cross section due to erosion caused a decrease of flow velocity to values that were not able to remove sediments from the bed.

\section{Flow throughout slotted pipe bottom outlet}

Observations of Case A suggest the flow pattern through the bottom outlet shown in Figure 6. The extremity of the outlet is kept clogged by sediments in a way that sediment removal only 
happens through the slots. As stated before, $\mathrm{L}_{\mathrm{smax}}$ is approximately constant for all slots. Therefore, it is possible to assume that inflow velocity at the slots is constant along the structure. Furthermore, as the slots are identical, it is inferred that the discharges are as well constant for all slots and that its sum results in the total discharge flowing through the bottom outlet. Considering the slot area as the surface area of the external diameter regarding one slot (Figure 7) and the continuity equation, the inflow velocity in a slot may be written as

$u_{r}=\frac{Q_{r}}{A_{r}}=\frac{Q_{r}}{\pi(D N / 2) R}$

in which $\mathrm{u}_{\mathrm{r}}=$ mean inflow velocity at a slot, $\mathrm{Q}_{\mathrm{r}}=$ slot discharge, $\mathrm{A}_{\mathrm{r}}=$ slot area, and $\mathrm{R}=$ slot width.

Case B is very similar to Case A, however, flow passes through the slots and the circular orifice at the bottom outlet's end as depicted in Figure 8.

Since it was observed a flushing range $40 \%$ greater in the pipe extremity than in the slots and that the orifice area is much bigger than the slot area, it is inferred that the discharge is greater in the orifice as well when compared to a single slot. However, there is no sufficient data to calculate directly the slot discharge and the orifice discharge as there were no experimental measures of flow velocity. Nevertheless, the constant flushing range by the slots out of the influence zone of the circular orifice makes reasonable assuming that, accordingly to Figure 8, Equations 3 and 4 are valid.

$$
\begin{aligned}
& Q_{1} \approx Q_{2} \approx Q_{3} \approx Q_{4} \approx Q_{5}<Q_{6} \\
& Q=Q_{1}+Q_{2}+Q_{3}+Q_{4}+Q_{5}+Q_{6}
\end{aligned}
$$

in which $\mathrm{Q}_{6}=$ circular orifice discharge.

\section{Profile analysis}

Figure 9 presents the position of the profiles that are considered sufficient for characterizing the geometry of the scour pit generated by the slotted pipe bottom outlet. The sidewalls of the channel and the dam wall in relation to the scour pit location may be seen as well. This paper only analyzes the sediment removal by the slots; consequently, only profiles $\mathrm{P} 2$ and P5 are detailed. In the direction of P2 and P5 profiles, the number of points surveyed from the scour pit depended on the extent of the scour, but at least 6 points were surveyed with the laser distance measurer for each experiment. These points were interpolated to obtain the contour levels from which the profiles were extracted.

Figure 10 presents P2 and P5 profiles for the experiments respective to sand as sediment (symbol shape depends on pipe diameter). It is noticeable the variation of $\mathrm{L}_{\mathrm{s}}$ as a function of outlet diameter and discharge. Particularly, it is observed an increase in $\mathrm{L}_{\mathrm{s}}$ with increasing diameter. The slope of the scour pit bed profile is nearly the same in all experiments with sand regardless of diameter and discharge. Its slope (approximately $30^{\circ}$ with the horizontal plane) is very similar to the repose angle of the employed sand $\left(29.5^{\circ}\right)$, what confirms the results

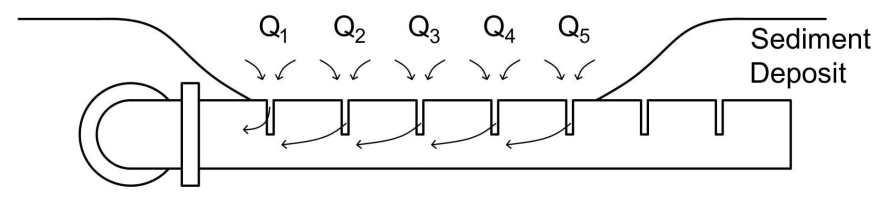

Figure 6. Flow pattern in Case A.

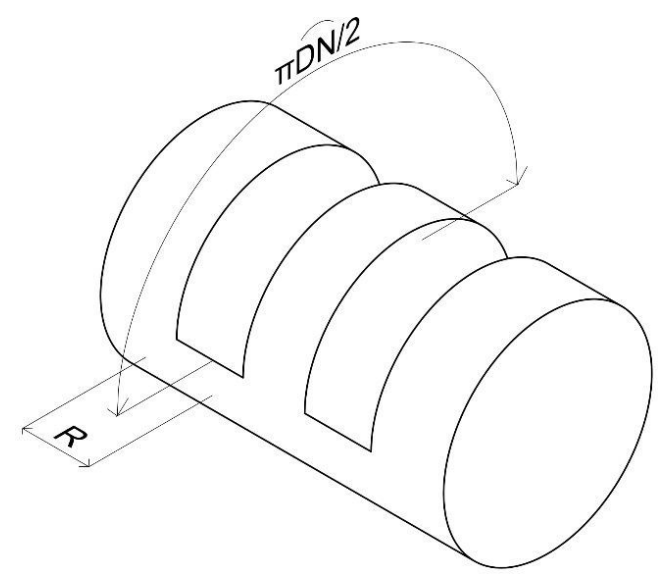

Figure 7. Dimensions that define a slot.

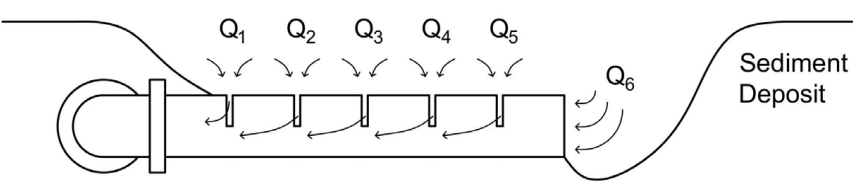

Figure 8. Flow pattern in Case B.

of previous studies such as Scheuerlein et al. (2004), FathiMoghadam et al. (2010) and Sawadogo et al. (2019). It may also be noticed that slots tend to remove sediment in lower elevations with the increase in outlet diameter. Since the profile slope is practically constant, greater removal is observed with increasing diameter because the profile is displaced away from the structure to maintain its slope.

Figure 11 compares the variation of $\mathrm{L}_{\mathrm{s}}$ for each diameter as a function of sediment type. The value of $\mathrm{L}$ in experiments with sand is, in general, greater or equal to $\mathrm{L}_{\mathrm{s}}$ obtained in experiments with rubber. These results may seem to disagree with the expected results prior to the execution of experiments since the flushing range should increase with a decrease in sediment density (Abreu, 2019; Fathi-Moghadam et al., 2010), that is to say, rubber should have been eroded more easily than sand due to its lower density. However, the repose angle of rubber is appreciably greater than the repose angle of sand and, as stated before, the scour pit slope tends to be similar to the repose angle of sediment. The greater repose angle of rubber granules in comparison with sand is due to its greater diameter in some extent but is particularly due to its shape factor. Rubber granules are much sharper and have a more angular format than the sand grains. Despite the expected influence of sediment density not being observed in the flushing range due to the prevalence of the repose angle of rubber granules in the final slope of the scour pit profile, it is believed that the deviation 

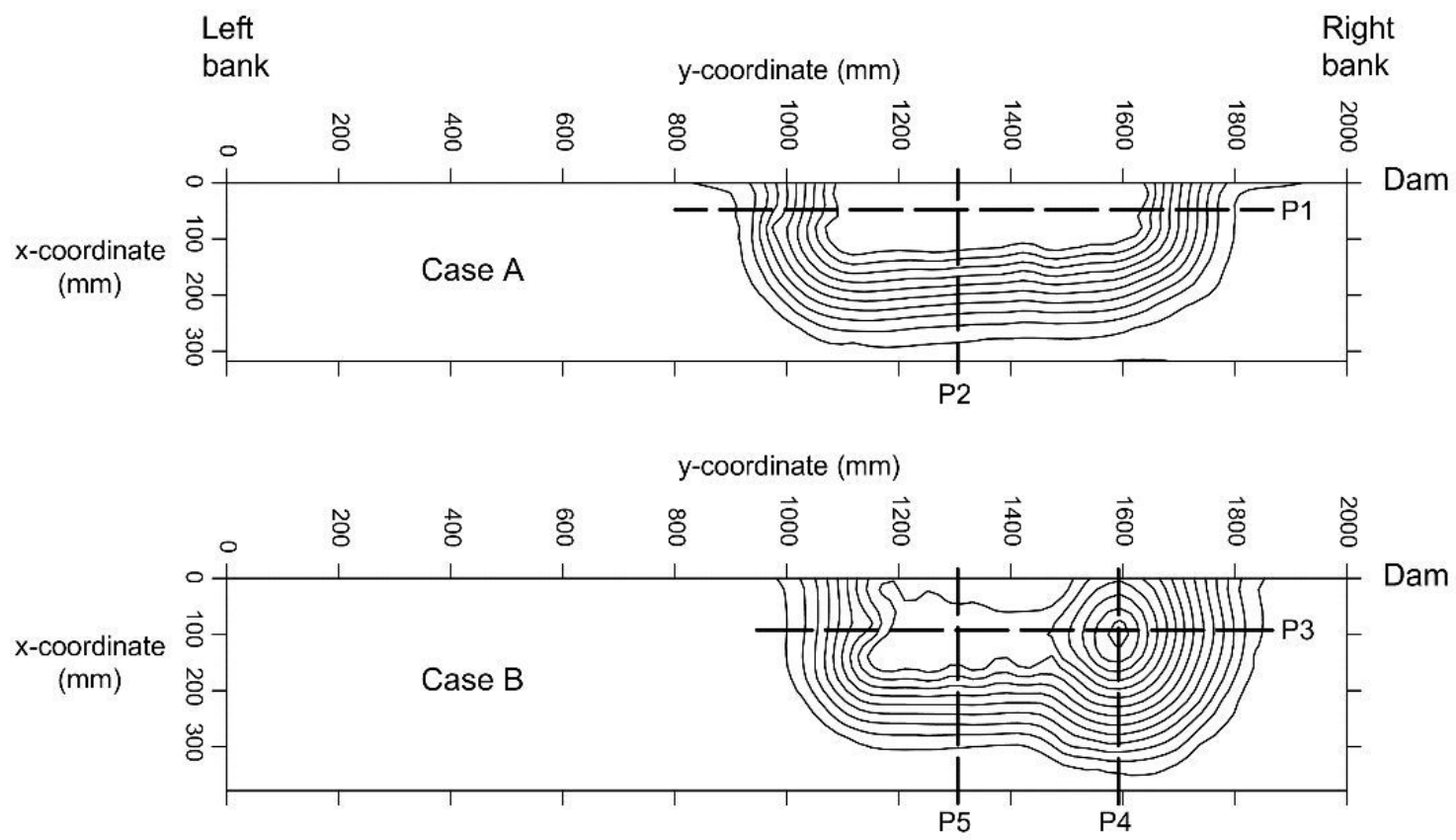

Figure 9. Profiles that characterize scour pit dimensions in Cases A (DN50; 2.19 l/s) and B (DN75; 5.70 1/s).

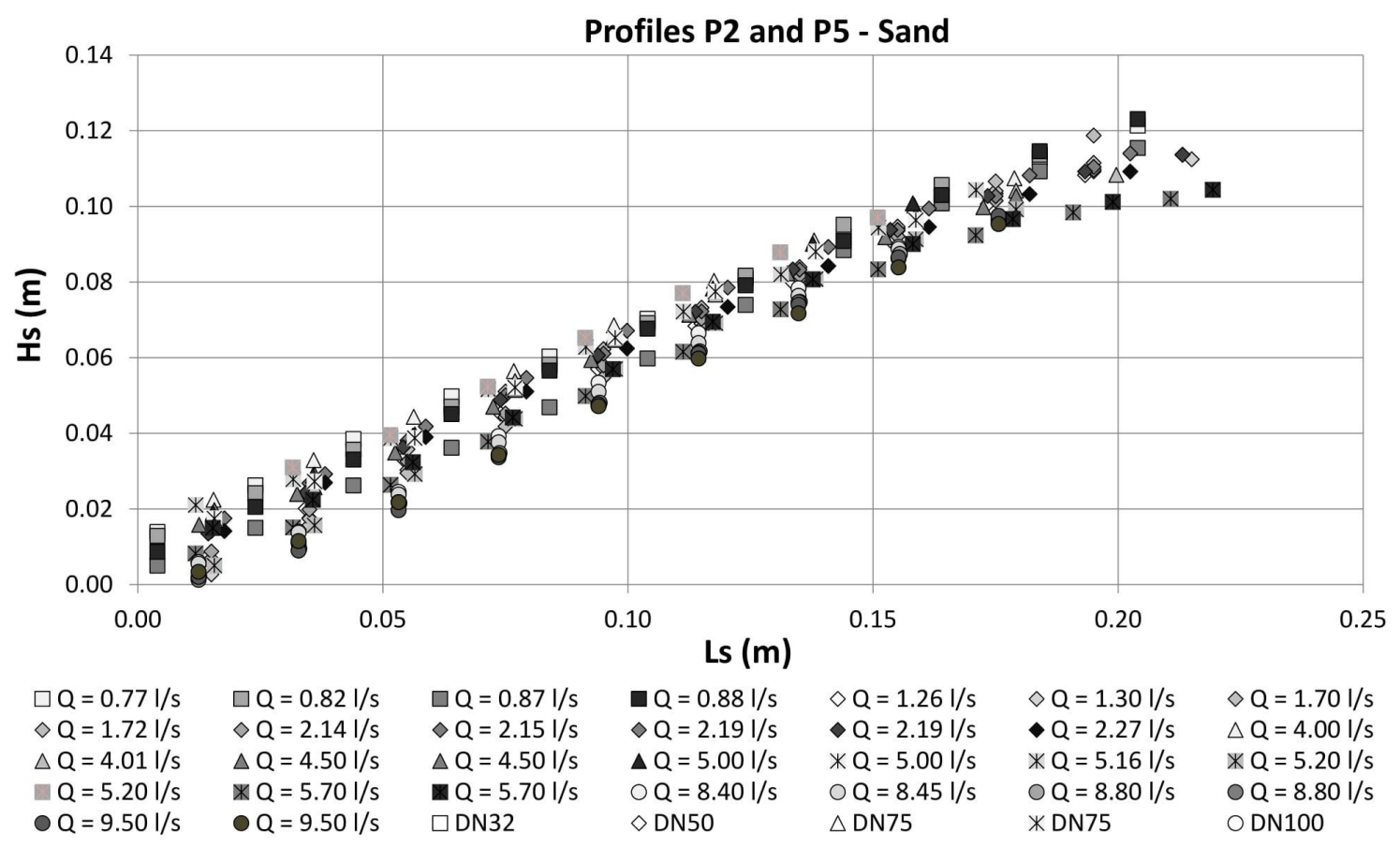

Figure 10. Profiles P2 and P5 generated by slots in experiments with sand as sediment. Symbol shape depends on pipe diameter.

from rubber repose angle as discharge and pipe diameter increased comes from its lower density. Rubber granules are more erodible than sand when taking into account density and grain diameter (for example, Shields number considering the same bed shear stress for both sediments is 1.082 for rubber and 0.089 for sand, i.e. rubber is more easily scoured than sand). Hence, a same increment in discharge should be able to remove more rubber than sand and this is believed to be the reason for the profile slope respective to rubber granules to become milder with increasing discharge and why it was not observed with sand. Possibly, it would require a greater increase in discharge to make profile slopes concerning sand less steep than its repose angle.

Another effect of particle density may be noted in the sediment removal below slot base elevation. Abreu (2019) conducted experiments with four materials of different densities and noted that sediment removal below outlet invert increases with decreasing density. Indeed, in this article, it was observed some sediment removal below slot base elevation in experiments with sand $\left(\varrho=2160 \mathrm{~kg} / \mathrm{m}^{3}\right)$. However, in experiments with rubber granules $\left(\varrho=1080 \mathrm{~kg} / \mathrm{m}^{3}\right)$ and DN100 (greater discharges), the 

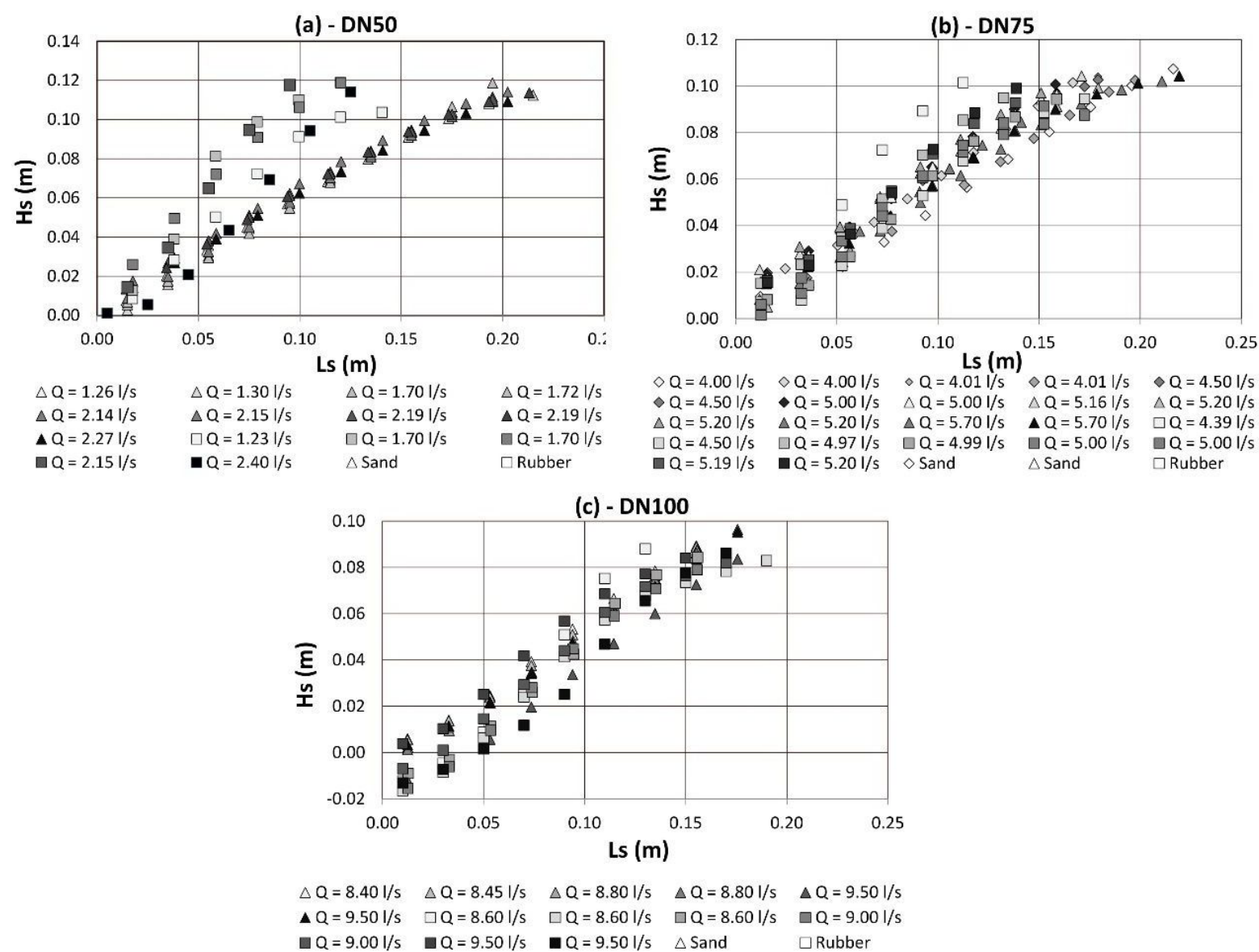

Figure 11. Profiles P2 and P5 generated by slots in experiments with rubber and sand as sediments ordered by pipe diameter.

placement of the bottom of the profiles in negative elevations (below slot base) is remarkable. In other words, as discharge and pipe diameter increase, the expected differences due to variation of sediment density become visible because the effect of shape factor becomes less important than particle density influence. These results indicate that in experimental installations for this type of investigation it is necessary to consider the shape factor of grains in the election of materials for representing sediment in order to properly evaluate the effect of other variables like particle density and particle diameter.

\section{Estimation of flushing range}

The search for an equation that represents the functioning of the slots of the proposed structure took place through the nondimensionalisation of profiles $\mathrm{P} 2$ for Case A because it is the only observed situation in which it is possible to calculate inflow velocity at the slots from Equation 2 directly.

The relation that allows localizing a point in the vertical direction of a profile for any scour pit was defined by Equation 5

$H_{s}^{*}=\frac{H_{s}}{H_{\text {smáx }}}$

in which $\mathrm{H}_{\mathrm{s}}^{*}$ varies from 0 to $1 ; 0$ value is related to slot base elevation and 1 is related to the surface of sediment deposit (see
Figure 3). It was aimed a relation between the dimensionless groups of Equation 1 with $\mathrm{H}^{*}$ along the profiles obtained experimentally. In this way, the resulting equation would allow predicting the entire scour pit profile generated by the slots of the slotted pipe bottom outlet. Figure 12 presents the dimensionless relation obtained between $\mathrm{H}_{\mathrm{s}}^{*}$ and $\Pi^{*}$, which is given by Equation 6

$\Pi^{*}=\left(\frac{H_{w}}{H_{s}}\right)^{0.5}\left(\frac{L_{s}}{D_{\text {int }}}\right)^{-0.5}\left(\frac{u_{r}}{\sqrt{g d}}\right)^{-0.5}\left(\frac{\rho_{s}-\rho}{\rho}\right)^{0.15}$

The first two terms in the right-hand side of Equation 6 vary along the profiles observed in the experiments and represent the shape of the nondimensionalised profiles in Figure 12, whereas the two latter terms are constants for one particular profile, varying between experiments.

As in the works of other authors (Emamgholizadeh \& Fathi-Moghdam, 2014; Kamble et al., 2018; Meshkati et al., 2010), $H_{w} / H_{s}$ poses as an important parameter for describing the phenomenon. Parameter $\mathrm{L}_{\mathrm{s}} / \mathrm{D}_{\text {int }}$ allows, by solving the equation for $\mathrm{L}_{\mathrm{s}}$, estimating the length of the scour pit generated by the proposed bottom outlet. The parameter that considers $u_{r}$ is similar to the modified Shields parameter employed in the dimensionless equation proposed by Fathi-Moghadam et al. (2010) (Equation 7) with the difference that the relation between densities is taken into account in another dimensionless group: 


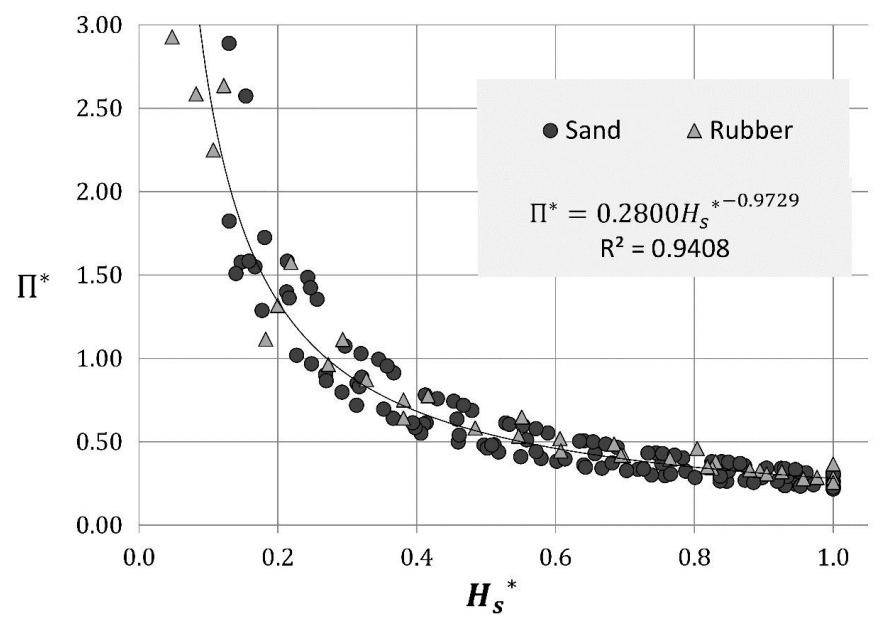

Figure 12. Dimensionless relation obtained for estimation of $\mathrm{L}_{\mathrm{s}}$.

$\frac{L}{D}=8.19\left(\frac{u}{\sqrt{g\left(G_{s}-1\right) d_{50}}}\right)^{0.10}\left(\frac{H_{s}}{H_{w}}\right)^{-0.033}$

where $G_{s}$ is the specific gravity of sediment and $d_{50}$ is the mean grain diameter of non-cohesive sediment.

It was considered important to utilize the same modified Shields parameter, however, the relation between densities came out less representative than the other parameters for it is raised to 0.1 power. This does not mean that the phenomenon is weakly dependent on particle density at all, but only that there was not enough difference among observed profiles from experiments with sand and rubber to the relation of densities to be more relevant. It is believed that this low observed difference is the product of the rubber granules shape factor effect previously discussed. Albeit shape factor has turned up important in some experiments, the results showed that its influence decreases with increasing values of discharge and bottom outlet diameter. In prototype scale, those variables values must be much greater than the ones employed in this article, whereas particle diameter should not increase in the same proportion. In Brazilian reality, for instance, particle diameter ranges from medium gravel to medium silt. Therefore, the shape factor influence must be less relevant and this is why it was disregarded in the dimensionless equation proposed.

Given those considerations, the dimensionless relation proposed may be used for estimating the length of scour pit generated by a slotted pipe bottom outlet between these limits: $\frac{H_{w}}{H_{\text {smáx }}}$ from 1.38 to $3.94 ; \frac{u_{r}}{\sqrt{g d}}$ from 3.24 to $10.53 ; \frac{\rho_{s}-\rho}{\rho}$ from 0.08 to $1.61 ; \frac{H_{\text {smáx }}}{D_{\text {int }}}$ from 1.35 to 4.64 .

\section{CONCLUSIONS}

The silting of water intakes is an issue that can severely affect dam operation, especially when there is a need for placing them far from the deepest regions of the reservoir. Thus, a new structure of bottom outlet that allows an increase of sediment removal in the direction parallel to the dam axis was proposed. Its operation was verified in terms of the form of the scour pit generated and of the influence of its diameter, sediment type, and flow conditions.

A dimensionless equation for predicting the flushing range due to slots was presented. It is important, however, to pay attention to its limitations. The sediments employed are noncohesive and, mainly sand, poorly graded so that the equation showed in Figure 12 should be applied with caution when working with sediment deposits of well graded or gap graded grain size distribution. In a prototype, the sediment type that deposits close to the dam may be very fine, possibly cohesive. Erosion processes of cohesive sediments are not equal to the scouring of non-cohesive ones, mostly if deposits possess some degree of consolidation (situation in which sediment removal will be reduced). In addition, the sediment reaching the dam may deposit inside the slotted pipe through the slots, filling the structure in the period between consecutive operations and ultimately resulting in malfunctioning of the outlet setup. Therefore, it is advisable to develop a regular operation plan to avoid clogging of the system and consolidation of deposits.

Damage due to cavitation (high flow velocity) and erosion (high flow velocity associated with high sediment concentration) is an aspect that is generally considered in the design of conduits in dams and that have been reported in bottom outlet operation (Amirsayafi, 2015). The design of the slotted pipe bottom outlet should be no different from traditional bottom outlets in this aspect since it will face the same type of heavily sediment-laden and high-velocity flow. Therefore, a material resistant to the abrasion caused by the flow should be selected for construction of the structure.

Given those reservations, the proposed equation may be used to predict erosion profiles generated by the slotted pipe bottom outlet in preliminary design, not excluding the need for studying particular cases through physical and mathematical modeling. The proposed structure should be incorporated into real dams in order to evaluate its effectiveness and the validity of the proposed dimensionless equation.

The following investigation suggestions should be carried out in order to further develop the knowledge about the functioning of the slotted pipe bottom outlet: operate the structure under greater hydraulic heads (the experimental installation employed was limited to a maximum of $43 \mathrm{~cm}$ of water column over the invert of bottom outlets); experimentally measure local velocities in order to know the discharge distribution along the structure and, hence, be able to analyze the remaining profiles described in this article, obtain the discharge coefficient and evaluate the head losses; develop an equation for determining whether Case A or Case B will take place and how many slots may be cleared; employ other configurations of width and spacing between slots; employ sediments with other densities and diameters and with de least relevant shape factor effect as possible.

\section{ACKNOWLEDGEMENTS}

The authors would like to acknowledge the journal editors and reviewers for their comments and suggestions and the Instituto de Pesquisas Hidráulicas and UFRGS for the facilitation of the experiments. This work was partially supported by the Brazilian agency CAPES. 


\section{REFERENCES}

Abreu, A. S. (2019). Análise experimental em modelo físico de estruturas bidráulicas de remoção de sedimentos em barragens: descarregadores de fundo (Dissertação de mestrado). Centro de Desenvolvimento Tecnológico, Universidade Federal de Pelotas, Pelotas.

Abreu, A. S., Oliveira, V. L., Cunico, P. G. R., Camargo, P. L. B, Ferla, R., \& Barreira Martinez, C., Martinez, C. B., Endres, L. A. M., Sanagiotto, D. G., Prá, M. D., Teixeira, E. D., \& Marques, M. G. (2018). Análise preliminar do alcance de remoção de sedimentos por descarregadores de fundo em pequenas barragens. In Trabajos Completos del XXVIII Congreso Latinoamericano de Hidráulica (pp. 2788-2797). Buenos Aires, Argentina.

Amirsayafi, P. (2015). Measures for success in dam bottom outlet design. GSTF Journal of Engineering Research, 3(3), 111-117. http:/ / dx.doi.org/10.7603/s40707-014-0030-2.

Atkinson, E. (1996). The feasibility of flushing sediment from reservoirs. UK: HR Wallingford.

Campello, B. S. C. (2017). Estudo da velocidade de queda e do inicio do movimento das particulas de borracha e areia (Dissertação de mestrado). Escola de Engenharia, Universidade Federal de Minas Gerais, Belo Horizonte. Retrieved in 2020, April 25, from http://hdl.handle. net/1843/RAOA-BBQPSN

Chaudhary, H. P., Isaac, N., Tayade, S. B., \& Bhosekar, V. V. (2019). Integrated $1 \mathrm{D}$ and $2 \mathrm{D}$ numerical model simulations for flushing of sediment from reservoirs. IS H Journal of Hydraulic Engineering, 25(1), 19-27. http://dx.doi.org/10.1080/09715010.2018.1423580.

Chaudhry, M. A., \& Rehman, H. (2012). Worldwide experience of sediment flushing through reservoirs. Mehran University Research Journal of Engineering \& Technology, 31(3), 395-408.

Emamgholizadeh, S. (2012). Neural network modeling of scour cone geometry around outlet in the pressure flushing. Global NEST Journal, 14(4), 540-549.

Emamgholizadeh, S., \& Fathi-Moghdam, M. (2014). Pressure flushing of cohesive sediment in large dam reservoirs. Journal of Hydrologic Engineering, 19(4), 674-681. http://dx.doi.org/10.1061/(ASCE) HE.1943-5584.0000859.

Emamgholizadeh, S., Bina, M., Fathi Moghadam, M., \& Ghomeyshi, M. (2006). investigation and evaluation of the pressure flushing through storage reservoir. Journal of Engineering and Applied Sciences, 1(4), 7-16.

Empresa de Pesquisa Energética - EPE. (2019). Balanço energético nacional 2019: ano base 2018. Retrieved in 2020, April 25, from https://www.epe.gov.br/pt/publicacoes-dados-abertos/publicacoes/ balanco-energetico-nacional-2019

Fathi-Moghadam, M., Emamgholizadeh, S., Bina, M., \& Ghomeshi, M. (2010). Physical modelling of pressure flushing for desilting of non-cohesive sediment. Journal of Hydraulic Research, 48(4), 509-514. http://dx.doi.org/10.1080/00221686.2010.491691.
George, M. W., Hotchkiss, R. H., \& Huffaker, R. (2017). Reservoir sustainability and sediment management. Journal of Water Resources Planning and Management, 143(3), 04016077. http://dx.doi. org/10.1061/(ASCE)WR.1943-5452.0000720.

Juracek, K. E. (2015). The aging of America's reservoirs: in-reservoir and downstream physical changes and habitat implications. Journal of the American Water Resources Association, 51(1), 168-184. http:/ / dx.doi.org/10.1111/jawr.12238.

Kamble, S. A., Kunjeer, P. S., Sureshkumar, B., \& Isaac, N. (2018). Hydraulic model studies for estimating scour cone development during pressure flushing of reservoirs. ISH Journal of Hydraulic Engineering, 24(3), 337-344. http://dx.doi.org/10.1080/0971501 0.2017 .1381577 .

Kondolf, G. M., Gao, Y., Annandale, G. W., Morris, G. L., Jiang, E., Zhang, J., Cao, Y., Carling, P., Fu, K., Guo, Q., Hotchkiss, R., Peteuil, C., Sumi, T., Wang, H.-W., Wang, Z., Wei, Z., Wu, B., Wu, C., \& Yang, C. T. (2014). Sustainable sediment management in reservoirs and regulated rivers: experiences from five continents. Earth's Future, 2(5), 256-280. http://dx.doi.org/10.1002/2013EF000184.

Lai, J. S., \& Shen, H. W. (1996). Flushing sediment through reservoirs. Journal of Hydraulic Research, 34(2), 237-255. http:// dx.doi.org/10.1080/00221689609498499.

Madadi, M. R., Rahimpour, M., \& Qaderi, K. (2017). Improving the pressurized flushing efficiency in reservoirs: an experimental study. Water Resources Management, 31(14), 4633-4647. http://dx.doi. org/10.1007/s11269-017-1770-y.

Mahmood, K. (1987). Reservoir sedimentation: impact, extent and mitigation (World Bank Technical Paper, No. WTP71). Washington: World Bank.

Meshkati, M. E., Dehghani, A. A., Naser, G., Emamgholizadeh, S., \& Mosaedi, A. (2009). Evolution of developing flushing cone during the pressurized flushing in reservoir storage. International Journal of Environmental and Ecological Engineering Engineering, 3(10), 355-359. http://dx.doi.org/10.5281/zenodo.1058206.

Meshkati, M. E., Dehghani, A. A., Sumi, T., Mosaedi, A., \& Meftah H, M. (2010). Experimental investigation of pressure flushing technique in reservoir storages. Water and Geoscience, (54), 132-137.

Sawadogo, O., Basson, G. R., \& Schneiderbauer, S. (2019). Physical and coupled fully three-dimensional numerical modeling of pressurized bottom outlet flushing processes in reservoirs. International Journal of Sediment Research, 34(5), 461-474. http:// dx.doi.org/10.1016/j.ijsrc.2019.02.001.

Scheuerlein, H., Tritthart, M., \& Gonzalez, F. (2004). Numerical and physical modelling concerning the removal of sediment deposits from reservoirs. In F. Yazdandoost \& J. Attari (Eds.), Hydraulics of Dams and River Structures (pp. 328-341). London, UK: A.A.Balkema Publishers. http://dx.doi.org/10.1201/ b16994-34 
Schleiss, A. J., Franca, M. J., Juez, C., \& De Cesare, G. (2016). Reservoir sedimentation. Journal of Hydraulic Research, 54(6), 595614. http://dx.doi.org/10.1080/00221686.2016.1225320.

Taleb Bidokhti, N., \& Naghshineh, A. (2004). Flushing sediment through reservoirs. Indian Journal of Science and Technology, 28(B1), 119-136. Retrieved in 2020, April 25, from https://www.sid.ir/ En/Journal/ViewPaper.aspx?ID=14870

United Nations Educational, Scientific and Cultural Organization - UNESCO. (2019). The United Nations World Water Development Report 2019: leaving no one behind. New York: UN. https://doi. org/10.18356/0d8fe383-en.

Wen Shen, H. (1999). Flushing sediment through reservoirs. Journal of Hydraulic Research, 37(6), 743-757. http://dx.doi. org/10.1080/00221689909498509.

White, W. R., \& Bettess, R. (1984). The feasibility of flushing sediments through reservoirs. Wallingford: International Association of Hydrological Sciences.

World Commission on Dams. (2000). Dams and development: a new framework for decision-making. London: Earthscan Publications.

\section{Authors contributions}

Felipe Azevedo Paulo: Performed the methodology, obtained the results and wrote the text.

Aline Saupe Abreu: Performed the methodology and revised the text and the results.

Maurício Dai Prá: Contributed with technical notes and revised the text.

Luiz Augusto Magalhães Endres: Contributed with technical notes and revised the text.

Rute Ferla: Contributed with technical notes and revised the text.

Eder Daniel Teixeira: Defined the objectives and revised the text and the results.

Editor-in-Chief: Adilson Pinheiro

Associated Editor: Massimo Guerrero 